2014

\title{
Immigration Remarks for the 10th Annual Wiley A. Branton Symposium
}

Shoba S. Wadhia

Penn State Law

Follow this and additional works at: http://elibrary.law.psu.edu/fac_works

Part of the Immigration Law Commons

\section{Recommended Citation}

Shoba S. Wadhia. "Immigration Remarks for the 10th Annual Wiley A. Branton Symposium" Howard Law Journal 57.3 (2014). Available at: http://works.bepress.com/shoba_wadhia/29

This Article is brought to you for free and open access by the Faculty Works at Penn State Law eLibrary. It has been accepted for inclusion in Journal Articles by an authorized administrator of Penn State Law eLibrary. For more information, please contact ram6023@psu.edu. 


\title{
ESSAY
}

\section{Immigration Remarks for the 10th Annual Wiley A. Branton Symposium}

\author{
Shoba Sivaprasad Wadhia*
}

Good morning. Thank you to Richard Carlton and the Howard Law Journal for inviting me to speak today. Speaking at Howard carries special meaning for me for a few reasons. Like for many, my ideas about social justice and race came early and in part from the opinions of the late Thurgood Marshall, and so it is a privilege to feel his presence at Howard and to have Cecilia Marshall, wife of the late Thurgood Marshall in the audience. Also in 2008, I had the pleasure of teaching immigration law as an adjunct while working as a legislative lawyer in Washington D.C. For all of these reasons, it is an honor to be speaking at Howard School of Law.

This morning (despite the pressure that our panel comes right before lunch), I am going to provide a "101" on the role of prosecutorial discretion in immigration law, which is my primary area of research and fundamental to understanding how the immigration system operates. Prosecutorial discretion is a largely invisible tool that enables thousands, if not millions, of unauthorized noncitizens to reside in the United States without fear from deportation. It may be characterized as invisible because prosecutorial discretion decisions are largely connected to no action at all or as some call it, nonenforcement.

A favorable exercise of "prosecutorial discretion" refers to a decision by a Department of Homeland Security, or DHS, employee to abstain from enforcing the immigration laws against a person or group

* Samuel Weiss Faculty Scholar and Clinical Professor of Law at Pennsylvania State Dickinson School of Law. I thank the staff of the Howard Law Journal for their editorial assistance.

2014 Vol. 57 No. 3 
of persons. ${ }^{1}$ A grant of immigration prosecutorial discretion does not amount to a formal legal status but rather functions as a tenuous one. ${ }^{2}$ There are two or maybe three theories that lie beneath prosecutorial discretion in immigration law. One theory is economic. The agency has limited resources and deporting ten million people is not cost-effective (the agency has the resources to deport less than four percent or 400,000 of the total removable population). Therefore, the agency should target its resources toward its highest priorities such as those who present a risk to national security or a danger to the community. The second theory is humanitarian. There are scores of individualsyoung people pursuing higher education, spouses of U.S. military members, single mothers acting as primary breadwinners and caregivers, and migrant workers who left their families to build a life for themselves - who are contributing to the U.S. in meaningful ways and therefore, should be protected from deportation. ${ }^{3}$ There is a possible third theory that I might characterize as more political in nature that occurs when the agency chooses to exercise executive power in the wake of congressional inaction or action.

So what exactly does it mean to exercise prosecutorial discretion and at what stage of the immigration enforcement process may it be exercised? While you might hear the term "prosecutorial discretion" and associate it only with one action, or one form, there are in fact more than twenty different kinds of prosecutorial discretion, some with more fancy names than others. One policy document issued from the immigration agency in June 2011 lists the following examples, or forms, of prosecutorial discretion:

- deciding to issue or cancel a notice of detainer;

- deciding to issue, reissue, serve, file, or cancel a Notice to Appear ("NTA");

- focusing enforcement resources on particular administrative violations or conduct;

1. See, e.g., Shoba Sivaprasad Wadhia, The Role of Prosecutorial Discretion in Immigration Law, 9 Conn. Pub. Int. L.J. 243-244 (2010); Memorandum from Doris Meissner, Comm'r of Immigration and Naturalization Serv. on Exercising Prosecutorial Discretion 1 (Nov. 17, 2000) [hereinafter Meissner Memo] (on file with author); Memorandum from John Morton, U.S. Immigration and Customs Enforcement on Exercising Prosecutorial Discretion Consistent with the Civil Immigration Enforcement Priorities of the Agency for the Apprehension, Det., and Removal of Aliens 2 (June 17, 2011).

2. See, e.g., Wadhia, supra note 1 , at 246.

3. Id. at $244-45$. 
- deciding who to stop, question, or arrest for an administrative violation;

- deciding who to detain or to release on bond, supervision, personal recognizance, or other condition;

- seeking expedited removal or other forms of removal by means other than a form removal proceeding in immigration court;

- settling or dismissing a proceeding;

- granting deferred action, granting parole, or staying a final order of removal;

- agreeing to voluntary departure, the withdrawal of an application for admission, or other action in lieu of obtaining a formal order of removal;

- pursuing an appeal;

- executing a removal order; and

- responding to or joining in a motion to reopen removal proceedings and to consider joining in a motion to grant relief or a benefit. ${ }^{4}$

"Deferred action" is one form of prosecutorial discretion that has received some recent popularity in light of a 2012 program called Deferred Action for Childhood Arrivals or DACA. ${ }^{5}$ A less ornate form of prosecutorial discretion is when DHS refrains from filing a charging document called the Notice to Appear with the immigration court. ${ }^{6}$ When this notice is filed with the immigration court, removal proceedings are triggered and the noncitizen is all at once placed into an adversarial forum at which the government has alleged him as deportable and the immigration judge will hear arguments surrounding the noncitizen's relief from removal, should any be raised. ${ }^{7}$

Think about the decision to file or not to file the Notice to Appear, even where it appears legally sufficient. Thousands of dollars are saved-labor from the trial attorney, time for the immigration

4. Morton, supra note 1, at 2-3.

5. For the requirements for DACA from USCIS website, see Consideration of Deferred Action for Childhood Arrivals Process, U.S. Citizenship \& Immigration Servs. (last updated Jan. 18, 2013), available at http://www.uscis.gov/humanitarian/consideration-deferred-actionchildhood-arrivals-process.

6. See Immigration and Nationality Act $\S 239(a), 8$ U.S.C. $\S 1229 a(a)(1)$ (2012); 8 C.F.R. $\S \S 1003.13,1239.1$ (2014).

7. 8 C.F.R. $\$ 1003.14$; For more information about the role of NTAs during the prosecutorial discretion process, see New Report Calls for Improvements to DHS Notice to Appear Procedure, Penn ST. L. News (Oct. 22, 2013), available at http://law.psu.edu/news/new-re port-calls-improvements-dhs-notice-appear-procedure. 
judge, travel by all parties, time in detention if the individual is detained and so on. Likewise, the noncitizen is protected from the shame of a court proceeding and happy receiving his justice in a quieter or subtler way. Another way DHS may exercise prosecutorial discretion is to release a noncitizen from detention. ${ }^{8}$ Yet another way DHS may exercise discretion is to move to dismiss a case after removal proceedings have commenced or choose to not file an appeal with the administrative appellate court, the Board of Immigration Appeals, after the immigration judge sitting at the lower immigration court has determined that relief should be provided to the person. ${ }^{9}$

Prosecutorial discretion enjoys a rich history. The practice of prosecutorial discretion has existed for as long as the immigration system has operated but was first revealed in the early 1970s through some case law and a lawsuit involving a well-known music icon named John Lennon. ${ }^{10}$ In fact, one document, issued in 2000 by then INS Commissioner Doris Meissner, included pages of information about the theory of prosecutorial discretion and the types of equities that should be considered in deciding whether a favorable exercise of discretion is appropriate-some of these equities include: residence in the U.S., potential for an immigration benefit, and medical conditions affecting the individual or his family. ${ }^{11}$ The Meissner Memo also offers a good illustration of how guidance might be influenced by congressional activity or inactivity. ${ }^{12}$ The Meissner Memo was issued on the heels of the passage of two immigration laws by Congress in 1996, which together resulted in a statutory scheme that severely reduced the discretion once held by immigration judges and the federal courts in determining whether a person's equities or circumstances warranted a pardon or protection from deportation. The elimination of this discretion coupled with the creation of new grounds for deportation created a situation that made the agency look bad in media stories and public forums, at which the unintended consequences of the

8. See, e.g., Morton, supra note 1 , at 2; see also U.S. Immigration And Customs ENforcement, 11064.1: Facilitating Parental Interests in the Course of Civil ImmigraTION ENFORCEMENT ACtivities (2013), available at http://www.ice.gov/doclib/ detention-reform/ pdf/parental_interest_directive_signed.pdf.

9. See 8 C.F.R. $\$ 1239.1$ to .2 and 1240.15 ; see generally Exec. OFF. FOR IMMigr. Rev., http://www.justice.gov/eoir/ (last visited Jan. 21, 2014) (providing more information on the Executive Office for Immigration Review).

10. Leon Wildes, The Operations Instructions of the Immigration Service: Internal Guides or Binding Rules?, 17 San Diego L. Rev. 99, 101 (1979); see Wadhia, supra note 1, at 246.

11. See Meissner Memo, supra note 1 , at 7.

12. See id. at 1; Wadhia, supra note 1, at 252-254. 
1996 immigration laws were showcased (consider: a mom stealing a sweater and being labeled as an aggravated felony and barred from relief despite the presence of children born in the U.S. and enjoying lawful permanent residence or green card status for more than a decade). ${ }^{13}$ And there you have the possible third theory of prosecutorial discretion.

After the 9/11 attacks, Congress was swift in their deliberation about reorganizing the immigration agency (I know, hard to believe in the wake of a sixteen day furlough and delay on immigration reform) and in 2002, passed a bill called the Homeland Security Act of 2002, which abolished the Immigration and Naturalization Service (INS) and transferred key immigration units to a new cabinet agency called the Department of Homeland Security, or DHS. DHS handles three core functions-services, border protection and interior enforcement. ${ }^{14}$ These functions have names and acronyms-Immigration and Customs Enforcement (ICE), Customs and Border Protection (CBP), and U.S. Citizenship and Immigration Services (USCIS). So, you do the coordination math-these three units all play "share authority" to exercise prosecutorial discretion.

For the administrative law lovers in the room, appreciate that nearly every document issued by the INS and DHS on immigration prosecutorial discretion has been issued as a general policy statement and without notice and comment rulemaking under the Administrative Procedures Act (APA). In fact, when the courts tried to litigate whether or not the old Lennon rule (then known as an Operations Instruction) was a substantive benefit or merely an act of administrative convenience, the agency was quick to modify the rule to make clear that its prosecutorial discretion policy confers no right or benefit and, instead, acts solely as a convenience measure for the agency. ${ }^{15}$ Notably, prosecutorial discretion has historically lacked transparency. This was first revealed in the John Lennon case when Leon Wildes had to sue the agency before obtaining the files of some 1800 deferred

13. See, e.g., Nancy Morawetz, Understanding the Impact of the 1996 Deportation Laws and the Limited Scope of Proposed Reforms, 113 HARv. L. REv. 1936, 1957 (2000); see also Shoba S. Wadhia, Under Arrest: Immigrants' Rights and the Rule of Law, 38 U. Mem. L. Rev. 853, 871 (2008).

14. Department Components, Dep't of Homeland Security, http://www.dhs.gov/depart ment-components (last visited Feb. 6, 2014).

15. See Administrative Procedure Act, 5 U.S.C.A. $§ 553$ (West 2014); Shoba S. Wadhia, The Immigration Prosecutor and the Judge: Examining the Role of the Judiciary in Prosecutorial Discretion Decisions, 16 Harv. Latino L. Rev. 39, 41 n.4 (2013); see, e.g., Wadhia, supra note 1, at $248-49$. 
action cases but continued for many years thereafter. ${ }^{16} \mathrm{I}$, too, went through a Freedom of Information Act (FOIA) adventure that began with a skeletal request in 2009 and evolved into a lawsuit with one agency (ICE), regular communication with the FOIA office in the second one (USCIS), and little to no movement from the third (CBP). ${ }^{17}$

And for the budding criminal lawyers in the room, appreciate that immigration prosecutorial discretion bears some resemblance to criminal law, which historically has considered prosecutorial discretion since America's founding. Though the immigration law system is a civil one, it retains criminal law-like features such as interrogation, arrest, detention, the filing of charges, and in some cases a hearing before an immigration judge with the government serving as a "prosecutor" and the noncitizen serving as the "defendant." At each of these stages, DHS has the opportunity to exercise prosecutorial discretion. Like with the criminal system, the decision by DHS to bring and file charges against a person is a poignant stage in the enforcement process. ${ }^{18}$

The resemblances between the two systems were illustrated by early memos by INS like a memo published by Sam Bernsen in 1976 and the later one published by Doris Meissner in 2000-both of these memos recognized that while immigration officers are not prosecutors in the "literal" sense, they function as prosecutors in a certain practical way. ${ }^{19}$ The Meissner Memo went one step further by explicitly naming and referring to the United States Attorney's Manual and the federal "substantial federal interest standard" as a guidepost for the immigration agency. ${ }^{20}$ Finally, both the civil and criminal systems center the theory of prosecutorial discretion on saving resources and public interest or humanitarian reasons. Certainly, both systems have a broad list of conduct that makes a person prosecutable or deportable, so the resource constraints are as much actual as they are theo-

16. See generally Leon Wildes, The Nonpriority Program of the Immigration and Naturalization Service Goes Public: The Litigative Use of the Freedom of Information Act, 14 SAN DIEGO L. REv. 42 (1976-1977); see also Wadhia, supra note 1, at 246-248.

17. Shoba Sivaprasad Wadhia, Sharing Secrets: Examining Deferred Action and Transparency in Immigration Law, 10 U.N.H. L. Rev. 1, 4 (2012); see Shoba Sivaprasad Wadhia, My Great FOIA Adventure and Discoveries of Deferred Action Cases at ICE, 27 Geo. Immigr. L.J. 345 (2013); see also My FOIAs with DHS on Prosecutorial Discretion, available at http://papers .ssrn.com/sol3/papers.cfm?abstract_id=2195758.

18. See, e.g., Wadhia, supra note 1 , at 268.

19. Meissner Memo, supra note 1, at 4; Memorandum from Sam Bernsen, Gen. Counsel, on Legal Opinion Regarding Service Exercise of Prosecutorial Discretion (July 12, 1976), http:// www.ice.gov/doclib/foia/prosecutorial-discretion/service-exercise-pd.pdf.

20. Meissner Memo, supra note 1 , at 4. 
retical. There are some key differences between the civil and criminal law systems, some of which include the lack of a sentencing stage in immigration enforcement, the role of the victim in the criminal context and the lack of major due process protections in the immigration system like a court-appointed attorney, flexible rules about detention, and detention without charges or notice, and others. ${ }^{21}$

Let me fast forward to the last few years and highlight the role prosecutorial discretion has played during the Obama Administration. Early on, the Administration made public announcements about comprehensive immigration reform and legislative solutions to the broken immigration system. ${ }^{22}$ But the political landscape sharpened. The failure of Congress to pass the DREAM Act in 2010 was a setback for the Administration and thousands of young people who would have benefited from the bill. In addition to the failure of the DREAM Act, was the execution of deportation orders by the agency at record levels and public statements by the Administration about the importance of enforcement which one pundit called "enforcement on steroids." 23

Together, the demise of the DREAM Act, the inability of Congress to push immigration reform over the finish line, and a record number of deportations created a humanitarian crisis that activated the Executive branch to consider administrative solutions in the form of prosecutorial discretion. Beginning in late 2010, DHS published a collection of memoranda to outline its civil enforcement "priorities" and also identify the various factors that ICE employees and attorneys should consider in deciding whether prosecutorial discretion is appropriate. ${ }^{24}$ The Administration received support if not pressure from members of Congress, immigration advocates, Dreamers and law professors to exercise its prosecutorial discretion. ${ }^{25}$

21. See, e.g., Wadhia, supra note 1 , at 268-69.

22. For a sampling of President Obama's public discussion about comprehensive immigration reform, see David Jackson, Obama Talks Immigration with Officials-But No Members of Congress, USA Today (Apr. 19, 2011), http://content.usatoday.com/communities/theoval/post/ 2011/04/obama-talks-immigration-with-officials-but-no-members-of-congress/1\#.Ut1qK9Io5kg; see also Julie Mason, President Obama Pushes Immigration Overhaul, Politico.com (May 10, 2011), http://www.politico.com/news/stories/0511/54696.html; WhITE House, President Obama on Comprehensive Immigration Reform, http:/www.whitehouse.gov/photos-and-video/video/ president-obama-comprehensive-immigration-reform (last visited July 1, 2010).

23. Lost in Detention, FrontLINE, http:/www.pbs.org/wgbh/pages/frontline/race-multi cultural/lost-in-detention/transcript-11/ (last visited Jan. 21, 2014).

24. See e.g., Morton, supra note 1.

25. See A Sad Comparison: Napolitano's DHS, Tougher Than Bush, AmericA's Voice, http://americasvoiceonline.org/press_releases/a_sad_comparison_napolitanos_dhs_tougher_than _bush/ (last visited Feb. 6, 2014); Letter from the Senate Judiciary Subcomm. on Immigration to Janet Napolitano, Sec'y Dept. Homeland Sec. (Apr. 14, 2011), http://arnolaw.blogspot.com/2011/ 
Public interest over prosecutorial discretion peaked in June 2012 when President Barack Obama announced a policy termed DACA, or "Deferred Action for Childhood Arrivals." 26 DACA is a sort of deferred action which itself is a form of prosecutorial discretion in immigration law. DACA has enabled more than 500,000 young people to work and study in the United States with dignity and without the constant fear of arrest and possible deportation. ${ }^{27}$ Critics have labeled the memoranda on prosecutorial discretion and the DACA program, in particular, as excessive and politically motivated. ${ }^{28}$

Whether or not DACA was created for political reasons, the policy itself is nothing new and dates back to the John Lennon rule called the Operations Instruction. ${ }^{29}$ There have been concerns from both immigration restrictionists and activists about the implementation of the Morton Memos and the limitations of the DACA program. Some of these concerns include the fact that parents of Dreamers remain vulnerable to deportation, young people with minor offenses that constitute a "significant misdemeanor" are ineligible for DACA protection, and scores of parents with U.S. citizen children continue to sit in immigration detention or scheduled for deportation. ${ }^{30}$ This situation

04/letter-from-senate-judiciary.html; Letter from Senator Harry Reid et al. to President Barack Obama (Apr. 13, 2011), http://www.scribd.com/doc/53014785/22-Senators-Ltr-Obama-Relief-forDREAMers-4; Letter from Am. Immigration Lawyers Ass'n and Am. Immigration Council to Janet Napolitano, Sec'y, Dept. Homeland Sec. (Apr. 6, 2011), available at http://www.american immigrationcouncil.org/sites/default/files/docs/AILA-AIC-Napolitano-4-6-2011.pdf; Wadhia, supra note 17 , at 28 .

26. Consideration of Deferred Action for Childhood Arrivals Process, U.S. Citizenship \& IMMIGR. SERviCES, http://www.uscis.gov/tools/reports-studies/immigration-forms-data/data-setdeferred-action-childhood-arrivals (last visited Mar. 23, 2014).

27. Deferred Action for Childhood Arrivals, U.S. Citizenship \& Immigr. Services, http:// www.uscis.gov/sites/default/files/USCIS/Resources/Reports $\% 20$ and $\% 20$ Studies/Immigration $\% 2$ 0Forms\%20Data/All\%20Form \%20Types/DACA/daca-13-8-15.pdf (last visited Jan. 20, 2013).

28. See, e.g., Griselda Nevarez, Deferred Action Approval Rate Dispute Erupts Between Center for Immigration Studies and USCIS, Huffington Post (Apr. 29, 2013), http://www.huff ingtonpost.com/2013/04/29/deferred-action-approval-rate_n_3180073.html; Brad Plumer, Can Obama Legalize 11 Million Immigrants on His Own?, WASH. Post (Aug. 22, 2013), http://www. washingtonpost.com/blogs/wonkblog/wp/2013/08/22/marco-rubio-says-obama-could-legalize-11million-immigrants-on-his-own-is-that-right/; Hansi L. Wang, Deferred Action: A Bird in Hand for Young Immigrants, CoDE Switch (Apr. 23, 2013), http://www.npr.org/blogs/codeswitch/2013/ 04/23/178669698/Deferred-Action-A-Bird-In-Hand-For-Young-Immigrants.

29. Immigration and Naturalization Service, U.S. Department of Justice. Operations Instructions. Regulations and Interpretations, Sec. 103.1(a)(ii) (1952, as revised 1979).

30. See, e.g., Dreamer, DACA Recipient Yoli Navas: "We Live in Fear Every Day," AMERICA's VOICE (June 25, 2013), http://americasvoiceonline.org/blog/dreamer-daca-recipientyoli-navas-we-live-in-fear-every-day/; One Year Later: Report Shows Morton Memo Hasn't Delivered on Promises of Relief, REFORM IMMigr. FOR AM., http://www.reformimmigrationfor america.org/blog/item/1307-30one-year-later-report-shows-morton-memo-hasn-t-delivered-onpromises-of-relief.html (last visited Jan. 20, 2014); Seth F. Wessler, Nearly 205k Deportations of 
is not tolerable. Whether or not prosecutorial discretion can be a tool that delays deportation, each of these injustices is worthy of discussion.

\section{CONCLUSION}

Rather than offer possible solutions to each injustice of the immigration system in my final few minutes let me share a few that are specific to immigration prosecutorial discretion.

- DHS should increase transparency about the cases involving prosecutorial discretion; ${ }^{31}$

- DHS should hold employees who abuse prosecutorial discretion accountable and create more incentives for attorneys to do the right thing;

- DHS should issue fewer Notices to Appear against noncitizens who do not fit within the Administration's highest priorities ${ }^{32}$; and

- The Administration should recognize "deferred action" in the law as a formal benefit by promulgating a regulation. ${ }^{33}$

Thank you.

Parents of U.S. Citizens in Just over Two Years, ColonLines (Dec. 17, 2012), http://colorlines .com/archives/2012/12/us_deports_more_than_200k_parents.html.

31. For more on this recommendation, see Wadhia, supra note 17, at 51.

32. For more on this recommendation, see New Report Calls for Improvements to DHS Notice to Appear Procedure, PENN ST. L. News (Oct. 22, 2013), http://law.psu.edu/news/newreport-calls-improvements-dhs-notice-appear-procedure.

33. For more on this recommendation, see Wadhia, supra note 17, at 60-61. 
